\title{
ORGANOSOLV DELIGNIFICATION OF RESIDUAL PLANTATION WILLOW BARK AFTER EXTRACTIVE REMOVAL
}

\author{
*Matiss Pals ${ }^{1,2}$, Liga Lauberte ${ }^{2}$, Alexandr Arshanitsa ${ }^{2}$, Laima Vevere ${ }^{2}$, Vilhelmine Jurkjane ${ }^{2}$, Galina \\ Telysheva ${ }^{2}$ \\ ${ }^{1}$ Latvian State Institute of Wood Chemistry, Latvia \\ ${ }^{2}$ University of Latvia, Latvia \\ *Corresponding author's email: matiss232@gmail.com
}

\begin{abstract}
Plantation willows are commonly grown plants which are widely used for energetic purposes that does not correspond completely to its potential. To fully integrate this resource into biorefinery scheme, it is necessary to study optimal conditions of willow bark processing, aimed for separation of bark components, their comprehensive characterization and profitable practical application. Extraction of secondary metabolites is well known approach for bark processing. But the separation of the main cell wall components including lignin from the residual biomass is less studied. In this work plantation residual willow bark after extractives separation by two different solvents (acetone and ethanolwater) was used as a feedstock for Organosolv delignification. Effect of temperature and catalyst used on the yield and properties of lignin isolated from residual bark by ethanol-water treatment was studied. It was possible to obtain pure lignin with high yields (up to $41 \%$ ) that has the potential to be used for bio-plastic producing. Insoluble residue after delignification was carbohydrate rich (up to $80 \%$ ) feedstock allowing its practical use for bioethanol producing. Key words: plantation salix, proanthocyanidins, lignin, delignification, biorefinery.
\end{abstract}

\section{Introduction}

Willows are one of the most common woody plants grown on plantations for energy purposes (Szczukowski et al., 2012). Although their potential is very wide, willows are not currently being used to their full potential. Willow bark contains many valuable extracts, such as salicin, its derivatives and condensed tannins, mainly proanthocyanidins. The qualitative and quantitative composition of Willow bark extracts varies depending on the used willow breed, age, growing area and conditions. Multiple studies have been described, marking it as a source of polyphenolic compounds with strong antioxidant properties (Krasilnikova et al., 2018). However, to fully utilize willow bark as a resource, it is necessary to study the possible processing pathways for the residue left after extractives removal. The resulting bark residue after extraction can be used as a potential raw material for the separation of lignin and carbohydrates, which may further serve as feedstock to produce various high added value products. Lignin can be used as a renewable feedstock for polyurethane material or epoxide resin production (Hu, Zhang, \& Lee, 2018; Mathew et al., 2018) and/or as a natural antioxidative additive. Carbohydrates can be used as a source of glucose for production of bioethanol, furfural and its derivatives (Takkellapati, Li, \& Gonzalez, 2018; Naik et al., 2010). In recent years a lot of attention is being paid to Organosolv delignification methods. When compared to other more commonly used methods of delignification, Organosolv delignification is more in terms of green chemistry, it allows to separate lignin in sufficiently high yields and allows to obtain low condensed lignin that more closely resembles its native state. Although Organosolv delignification is studied quite extensively, it has not been widely applicated in processing of tree barks (Koumba-Yoya \& Stevanovic, 2017; Huijgen et al., 2014). In present work the delignification of residual willow bark in ethanol-water media in the presence of acid catalysts was studied in terms of lignin's yield, the presence of admixtures and hydroxyl groups content that will open the possibilities of lignin modification.

\section{Materials and Methods}

Materials and chemicals

All chemicals were of analytical grade and were purchased from Merck and used without further purification.

Samples

Plantation willow samples (variety 'Klara') were 3 years of age when taken from the plantation in Skriveri region in Latvia. Bark removed by a handle debarking was air dried (moisture content was 6\%) and then was ground to a smaller particle size $(<2 \mathrm{~mm})$ using Retch-100 cutting mill. Prior to use, the milled willow bark was stored in plastic bags in a freezer at $-18^{\circ} \mathrm{C}$.

Extractives removal as a pre-treatment of biomass

Two methods of extraction were compared. First one is Soxhlet extraction with acetone with accordance to TAPPI T-204 standard method. Around $10 \mathrm{~g}$ of ground willow bark was weighted into extraction thimble and inserted into Soxhlet apparatus with $100 \mathrm{~mL}$ of acetone. Total extraction time was 8 hours. Second method of extraction was performed with $50 \%(\mathrm{v} / \mathrm{v})$ ethanol/water solution under reflux. Around $25 \mathrm{~g}$ of ground willow bark was placed into round bottom flask and inserted into oil bath with temperature set to $80{ }^{\circ} \mathrm{C}$. Solution was heated under reflux for 2 hours. After that liquid was removed and fresh solvent was added. This procedure was repeated 
Used delignification conditions

\begin{tabular}{|c|c|c|c|}
\hline Abbreviation & Extraction method & Catalyst & $\mathrm{t},{ }^{\circ} \mathrm{C}$ \\
\hline K1 & Extraction with acetone & $4,5 \mathrm{mmol} \mathrm{FeCl}_{3}$ & 190 \\
\hline K2 & Extraction with $50 \%$ ethanol & $4,5 \mathrm{mmol} \mathrm{FeCl}_{3}$ & 190 \\
\hline K3 & Extraction with acetone & $9 \mathrm{mmol} \mathrm{FeCl}_{3}$ & 215 \\
\hline K4 & Extraction with $50 \%$ ethanol & $9 \mathrm{mmol} \mathrm{FeCl}_{3}$ & 215 \\
\hline K5 & Extraction with acetone & $15 \mathrm{mmol} \mathrm{H}_{2} \mathrm{SO}_{4}$ & 190 \\
\hline K6 & Extraction with $50 \%$ ethanol & $15 \mathrm{mmol} \mathrm{H}_{2} \mathrm{SO}_{4}$ & 190 \\
\hline
\end{tabular}

4 times and solutions removed were combined. After each extraction, solvent was removed using rotary evaporation, and around $100 \mathrm{~mL}$ of water was added. After that extracts were freeze dried using HETO POWER Dry PL3000 freeze-dryer.

Analysis of separated extracts

Folin-Ciocalteu method for determining total phenolic content in extracts and acid-butanol method for determining total proanthocyanidin content in extracts was performed as described in literature (Vieito et al., 2018). Identification of individual compounds in extracts were done using Waters Acquity H-Class UPLC system (USA) equipped with quaternary gradient pump, autosampler, temperaturecontrolled column department, diode array detector and Synapt G2-Si high resolution mass spectrometer (USA). CSH C18 $(1.7 \mu \mathrm{m}, 2.1 \times 100 \mathrm{~mm})$ column was used. Mobile phase consisted of $0.1 \%$ formic acid in water (A) and acetonitrile (B). Used ESI ions source, operated in negative ionisation mode. Identification of individual compounds were done by comparing obtained high resolution mass spectra with information available in Metlin database (Guijas et al., 2018).

\section{Organosolv delignification}

$25 \mathrm{~g}$ of extractives free willow bark, $250 \mathrm{~mL}$ of $50 \%(\mathrm{v} / \mathrm{v})$ ethanol/water solution and given amount of catalyst were loaded into 1 L PARR 4848 high pressure reactor, followed by heating and mixing under pressurized conditions (Table 1)

After 90 minutes of treatment, delignified biomass was separated from liquor by filtering. Liquor was concentrated in rotary evaporator and lignin was precipitated in $600 \mathrm{~mL}$ of ice-cold water, then filtered and washed with water till $\mathrm{pH}=5$ was reached. Remaining water-soluble fraction was freeze dried.
All acquired fractions were weighted after drying to determine full mass balance.

Analysis of separated fractions

Klason and acid soluble lignin content were determined using standard method (TAPPI T-222) (TAPPI, 2011). Py-GC/MS was carried out as described previously by colleges (Ponomarenko et al., 2014).

The monomeric sugars content in biomass was determined by the gas chromatography (GC-FID) method as described in (Blakeney et al., 1983) with slight modifications. $10 \mathrm{mg}$ of the sample was loaded into a screw tube, $0.125 \mathrm{ml}$ of $72 \% \mathrm{H}_{2} \mathrm{SO}_{4}$ was added and the mixture was incubated at room temperature for $3 \mathrm{~h}$. Then, $3.5 \mathrm{ml}$ of distilled water was added and then the mixture was incubated at $101{ }^{\circ} \mathrm{C}$ for $3 \mathrm{~h}$. The cooled sample was neutralized with $0.32 \mathrm{ml}$ of $\mathrm{NH}_{4} \mathrm{OH}$ and $0.1 \mathrm{ml}$ of methyl- $\alpha$-D-glucopyranoside solution $\left(20 \mathrm{mg} \mathrm{ml}^{-1}\right)$ was added as an internal standard. $0.2 \mathrm{ml}$ of the sample was taken, and $1 \mathrm{ml}$ of $2 \% \mathrm{NaBH}_{4}$ solution in dimethyl sulfoxide was added and the mixture was incubated at $40{ }^{\circ} \mathrm{C}$ for $90 \mathrm{~min}$. The excess of $\mathrm{NaBH}_{4}$ was decomposed by adding $0.1 \mathrm{ml}$ of glacial acetic acid. $2 \mathrm{ml}$ of acetic anhydride and $0.2 \mathrm{ml}$ of 1-methylimidazole were added to the solution and incubated at $40{ }^{\circ} \mathrm{C}$ for $10 \mathrm{~min}$. Then, $5 \mathrm{ml}$ of water was added, and the solution was extracted with $1 \mathrm{ml}$ of $\mathrm{CH}_{2} \mathrm{Cl}_{2}$ for 1 minute. The $\mathrm{CH}_{2} \mathrm{Cl}_{2}$ layer was collected for $\mathrm{GC}$ analysis.

\section{Results and Discussion}

Extraction results

The yield of extractives' results as well as the total phenolics and total proanthocyanidins content in them are shown in Table 2. All experiments were done in triplicate, results shown with standard deviations.

\section{The yield of extractives and their characteristic}

\begin{tabular}{|c|c|c|c|}
\hline Extraction method & Amount of extractives, $\%$ & TPC, \% & PAC, \% \\
\hline Extraction with Acetone & $17.8 \pm 0.3$ & $37.7 \pm 0.5$ & $23.2 \pm 0.5$ \\
\hline Extraction with $50 \% \mathrm{EtOH}$ & $36.1 \pm 0.5$ & $52.9 \pm 0.6$ & $27.9 \pm 0.4$ \\
\hline
\end{tabular}



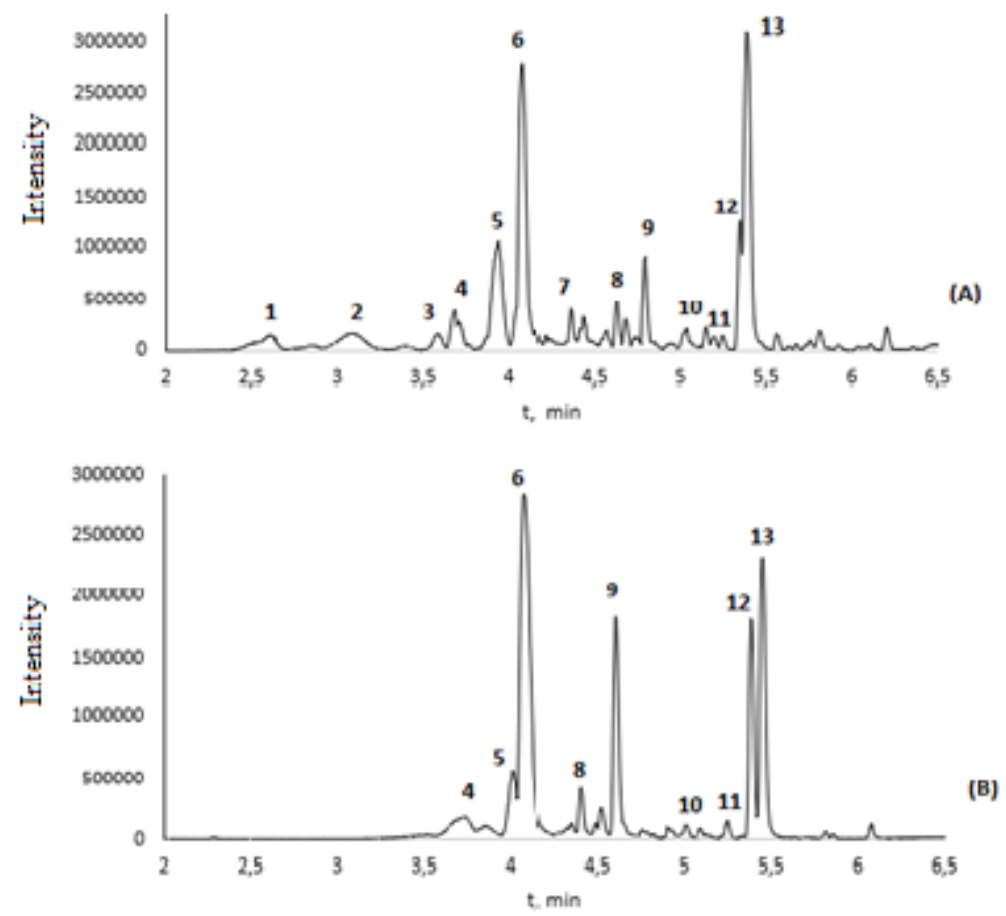

Figure 1. BPI chromatograms of separated extracts. (A) $50 \% \mathrm{v} / \mathrm{v}$ ethanol/water extract,

(B) acetone extract.

Comparison of the extraction results shows that using $50 \% \mathrm{v} / \mathrm{v}$ ethanol/water as extraction solvent yielded 2 times more extractives than when using acetone. Although acetone is a semi-polar extraction solvent and can extract a broader range of compounds (11), this result indicates that the willow bark extractives are predominantly polar compounds.
Individual compounds were identified in the obtained extracts using the UHPLC-MSMS system. The obtained chromatograms are shown in Figure 1. The results show that the extract obtained with $50 \%$ $\mathrm{v} / \mathrm{v}$ ethanol/water has more individual compounds, with a greater presence of both proanthocyanidins and salicylates.

Identification of individual compounds

\begin{tabular}{|c|c|c|c|}
\hline No. & {$[\mathrm{M}-\mathrm{H}]^{-}$} & $\mathrm{M}^{2}$ & Identification \\
\hline 1 & 305.066 & 261.075 & Gallocatechin \\
\hline 2 & 593.130 & 305.057 & Epicatechin - gallocatechin dimer \\
\hline 3 & 881.193 & 289.076 & Epicatechin - gallocatechin trimer \\
\hline 4 & 135.045 & 117.049 & 4-Hydroxyphenylacetaldehyde \\
\hline 5 & 577.135 & 289.077 & Epicatechin dimer \\
\hline 6 & 289.073 & 245.082 & Epicatechin \\
\hline 7 & 401.140 & 383.023 & \multirow{3}{*}{ Flavonoid glycoside } \\
\hline 8 & 415.161 & 383.092 & \\
\hline 9 & 473.166 & 293.084 & \\
\hline 10 & 423.402 & 405.118 & Salicortin \\
\hline 11 & 493.229 & 403.241 & \multirow{2}{*}{ Flavonoid glycoside } \\
\hline 12 & 421.128 & 331.142 & \\
\hline 13 & 569.167 & 447.224 & Acetyl-tremulacin \\
\hline
\end{tabular}


Composition of initial and extracted bark samples

Table 4

\begin{tabular}{|c|c|c|c|c|}
\hline Sample & KL, \% & ASL, \% & Cellulose content, \% & Ash content, \% \\
\hline Untreated bark & $21.3 \pm 0.8$ & $4.7 \pm 0.2$ & $21.4 \pm 0.4$ & $2.15 \pm 0.05$ \\
\hline Extracted with acetone & $26.0 \pm 0.9$ & $3.8 \pm 0.2$ & $23.4 \pm 0.7$ & $2.44 \pm 0.06$ \\
\hline Extracted with 50 \% ethanol & $29.2 \pm 1.5$ & $3.47 \pm 0.14$ & $24.9 \pm 0.5$ & $2.32 \pm 0.06$ \\
\hline
\end{tabular}

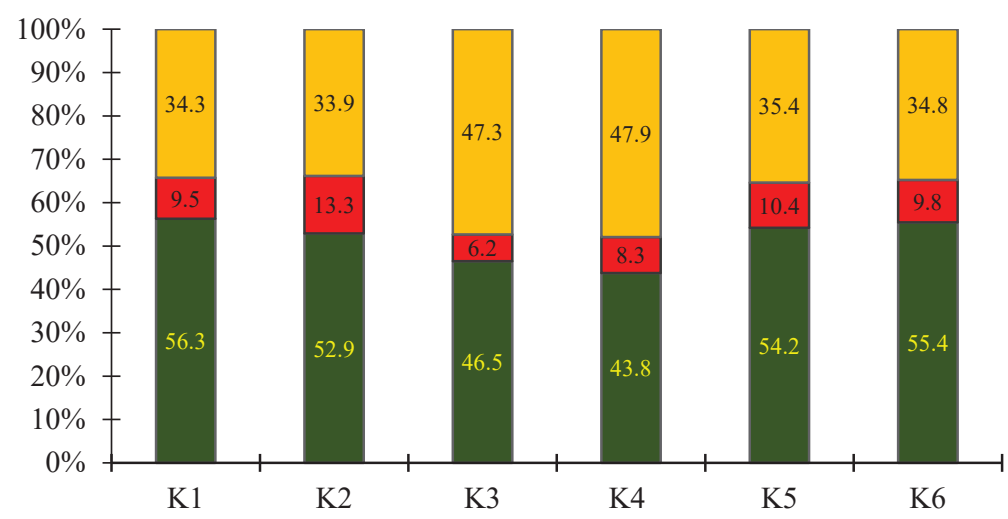

$\square$ Water soluble fraction, $\%$

- Lignin, \%

- Insoluble residue, \%

Figure 2. Mass balance of separated Organosolv fractions (abbreviations shown in Table 1).

In total 13 peaks were identified. The results obtained show that the predominant compounds of both extracts are proanthocyanidins as well as their monomers, epicatechin and gallocatechin. Various flavonoids and their derivatives, as well as salicin derivatives such as salicortin and acetyl-tremulacin, are also observed. Peak identification is shown in Table 3 with observed $[\mathrm{M}-\mathrm{H}]^{-}$ion and most pronounced fragment ion $\mathrm{M}^{2}$.

Delignification of residual bark after extraction

For the residual bark after extractives removal, Klason lignin (KL), acid soluble lignin (ASL), cellulose and ash content were determined. All experiments were done in triplicate, results shown with standard deviations. Obtained results are shown in Table 4.

Obtained results show that residual bark after removal of extractives is a potential feedstock of lignin and cellulose obtaining, since these main components are more concentrated in residual biomass. To separate individual components from residual bark after extractives removal, several delignification experiments were performed. Delignification conditions under study and abbreviation of samples are presented in Table 1. The mass balance of delignification processing as well as precipitated lignin yields on KL lignin content in biomass were calculated (Figures 2, 3).

It was shown that the yield of lignin in the case of delignification of residual bark after extractives removal by ethanol pre-treatment was higher in comparison with that obtained by delignification of acetone pre-treated bark (Figures 2, 3). According to the data (Koumba-Yoya et al., 2017), this can be explained by partial deactivation of catalyst due to formation of stable complex with phenolic of nonlignin origination extraction of which from bark by acetone was less effective.

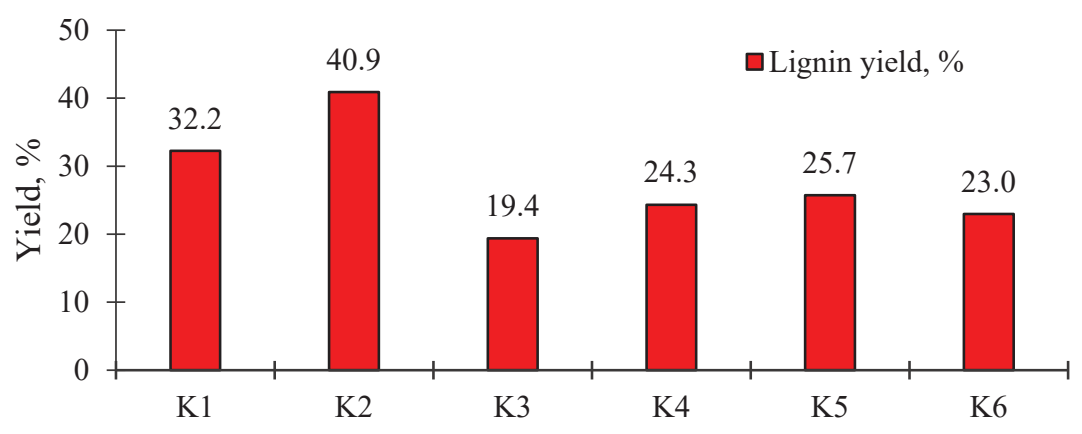

Figure 3. The yields of Organosolv lignin on KL content in biomass (Abbreviations shown in Table 1). 


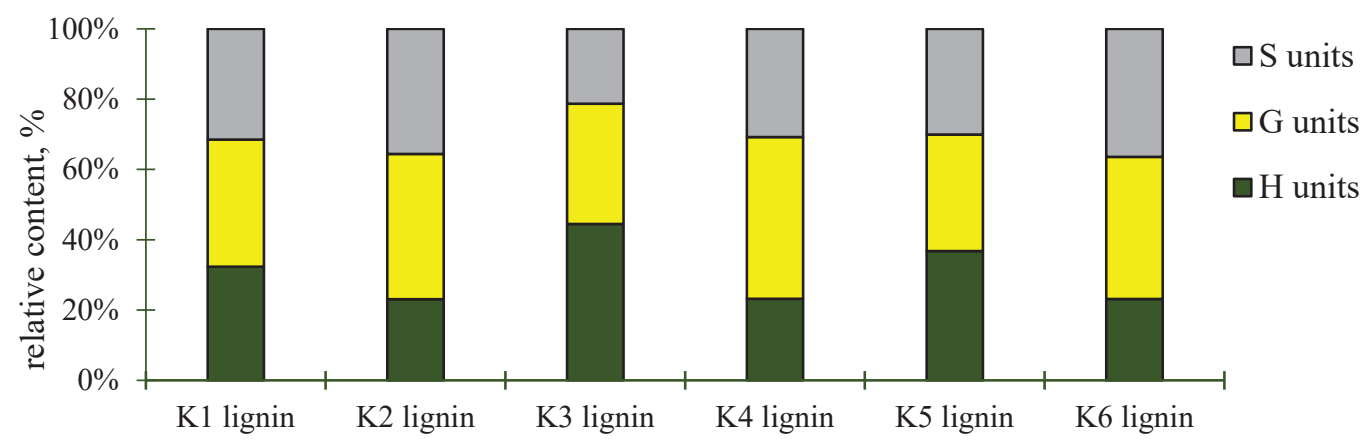

Figure 4. The relative content of lignin subunits in derived volatile products of lignin samples according to $\mathrm{Py}-\mathrm{GC} / \mathrm{MS}$ results.

The increasing of delignification temperature and amount of catalyst strongly promotes the transition of biomass components into the liquor. At higher temperature $\left(215^{\circ} \mathrm{C}\right)$ the yield of precipitated lignin is decreased, but the portion of products remaining in soluble state after lignin separation is increased significantly. Obviously, at high temperature solubilisation of hemicellulose and lignin in liquor is accompanied by their depolymerization. Noticeable higher positive effect of $\mathrm{FeCl}_{3}$ catalyst in comparison with $\mathrm{H}_{2} \mathrm{SO}_{4}$ on the yield of lignin was observed for bark residual after water-ethanol extraction. It was similar for both catalysts in case of acetone extracted bark.

\section{Analysis of obtained fractions}

The KL content in precipitated lignins varied in the range of $90-64.2 \%$. The lignin, isolated by delignification using $\mathrm{FeCl}_{3}$ as a catalyst, contained less of non-lignin admixtures. This was proven by GC-FID method. For lignin samples (K1-K4), isolated using $\mathrm{FeCl}_{3}$, the presence of carbohydrates admixtures was not observed. In lignin samples K5 and K6, isolated by sulphuric acid catalysed delignification, some content of carbohydrates was observed, (5.37\% For K5 and $6.54 \%$ for K6), meaning their chemically bonded incorporation into the lignin matrix.
It was established that separated lignins are $\mathrm{S} / \mathrm{G} / \mathrm{H}$ types of lignin, but the relative portion of different lignin subunits in them is changed in comparatively wide range depending on delignification regimes that obviously will influence their transformation during further chemical modification (Figure 4). For example, it can be prognosticating that lignin (K3), separated using enhanced amount of $\mathrm{FeCl}_{3}$ is characterized by the lower portion of methoxylated subunits, and therefore will be able for further undergoing of internal $\mathrm{C}-\mathrm{C}$ condensation using free 3,5 positions in aromatic ring. This transformation is not beneficial for further chemical modification due to decrease of heat mobility of polymeric chains. Such a type of lignin could be used as an active filler of thermosets due to action as a promoter of char formation enhancing the fire retardance properties of material. On the contrary, the K4 sample has the highest portion of methoxylated subunits in them indicating lower potential to self-condensation and therefore, high suitability for chemical modification and introducing in polymeric (polyepoxide, polyurethane) composition as a macromonomer. Other lignins take the middle between samples K3 and $\mathrm{K} 4$ samples position in terms of methoxylated lignin content in them.

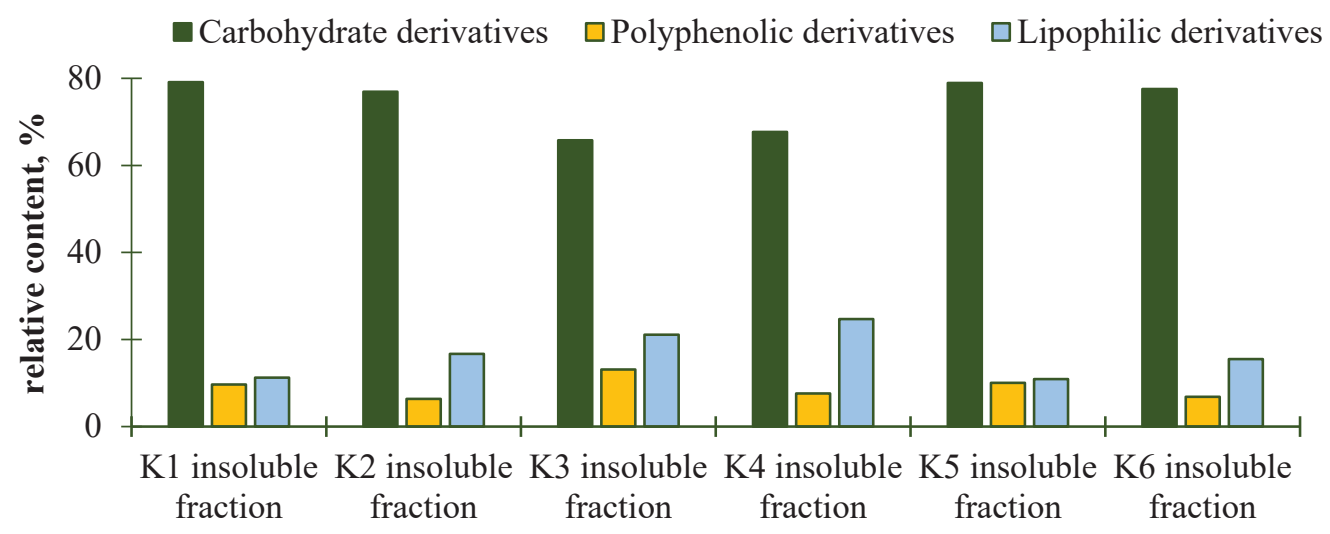

Figure 5. The relative content of main biomass components derived volatile products of residual barks samples after delignification according to Py-GC/MS results. 
The yield of insoluble part of dignified bark consisted between $45-55 \%$ on DM of extracts free bark. Therefore, the study of its composition for search of further valorisation is an important task in view of biorefinery approach.

It was determined by $\mathrm{Py}-\mathrm{GC} / \mathrm{MS}$ that residual biomass contains mainly (70-80\%) carbohydrate derivatives with some admixture of lignin and lipophilic compounds, obviously, consisted mainly of polyesters of suberin and paraffin (Figure 5). GC-FID method used for carbohydrate determination in these residues shows that after complete hydrolysis they contain only glucose, indicating that carbohydrate component of insoluble residue consists mainly from cellulose. The data of residual bark composition allow to characterize it as promising feedstock highly reached with cellulose in comparison with initial wood biomass, thus suitable for micro cellulose and/or bioethanol production. Due to presence of high calorific lipophilic compounds in residual bark biomass, application of it for heat and energy production can be recognized as one more direction of extractives free delignified bark valorisation.

\section{Conclusions}

1. The results obtained have shown that Plantation willow bark is a prospective renewable resource that can be incorporated into biorefinery schemes for obtaining value products added of different use.

2. Both extracts isolated by acetone and 50\% $\mathrm{EtOH} /$ water treatment of bark are rich with biologically active compounds - predominantly proanthocyanidins and salicin derivatives.

3. Residual bark after extractives removal can be further used as a feedstock for delignification. High purity (up to $90 \%$ ), carbohydrate admixtures free lignins can be obtained by delignification performed at $190-215{ }^{\circ} \mathrm{C}$, using $50 \%$ ethanol/ water solution in the presence of $\mathrm{FeCl}_{3}$ as a catalyst.

4. The isolated lignins have a potential to be used as a macromonomer in polyepoxide and polyurethanes compositions.

5. Insoluble residue after delignification is highly enriched with cellulose (up to 80\%) and could be used as a source of micro cellulose and/or hydrolysis feedstock, or as a solid biofuel source.

\section{Acknowledgements}

This study was financially supported by the Bioeconomic grant 'LignoBark' from the Latvian State Institute of Wood Chemistry

\section{References}

Blakeney, A.B., Harris, P.J., Henry, R.J., \& Stone, B.A.A. (1983). Simple and Rapid Preparation of Alditol Acetates for Monosaccharide Analysis. Carbohydr. Res. 113(2), 291-299. DOI: 10.1016/00086215(83)88244-5.

Guijas, C., Montenegro-Burke, J.R., Domingo-Almenara, X., Palermo, A., Warth, B., Hermann, G., Koellensperger, G., Huan, T., Uritboonthai, W., \& Aisporna, A.E. (2018). METLIN: A Technology Platform for Identifying Knowns and Unknowns. Anal. Chem. 90(5), 3156-3164. DOI: 10.1021/acs. analchem.7b04424.

Huijgen, W.J.J., Telysheva, G., Arshanitsa, A., Gosselink, R.J.A., \& de Wild, P.J. (2014). Characteristics of Wheat Straw Lignins from Ethanol-Based Organosolv Treatment. Ind. Crops Prod. 59, 85-95. DOI: 10.1016/j.indcrop.2014.05.003.

Hu, J., Zhang, Q., \& Lee, D.J. (2018). Kraft Lignin Biorefinery: A Perspective. Bioresour. Technol. 247, 11811183. DOI: 10.1016/j.biortech.2017.08.169.

Koumba-Yoya, G., \& Stevanovic, T. (2017). Transformation of Sugar Maple Bark through Catalytic Organosolv Pulping. Catalysts. 7(10), 294. DOI: 10.3390/catal7100294.

Krasilnikova, J., Lauberte, L., Stoyanova, E., Abadjieva, D., Chervenkov, M., Mori, M., De Paolis, E., Mladenova, V., Telysheva, G., \& Botta, B. (2018). Oregonin from Alnus Incana Bark Affects DNA Methyltransferases Expression and Mitochondrial DNA Copies in Mouse Embryonic Fibroblasts. J. Enzyme Inhib. Med. Chem. 33(1), 1055-1063. DOI: 10.1080/14756366.2018.1476504.

Mathew, A.K., Abraham, A., Mallapureddy, K.K., \& Sukumaran, R.K. (2018). Waste Biorefinery. India: Elsevier. DOI: 10.1016/B978-0-444-63992-9.00009-4.

Naik, S.N., Goud, V.V., Rout, P.K., \& Dalai, A.K. (2010). Production of First and Second Generation Biofuels: A Comprehensive Review. Renew. Sust. Energ. Rev. 14(2), 578-597. DOI: 10.1016/j.rser.2009.10.003.

Ponomarenko, J., Dizhbite, T., Lauberts, M., Viksna, A., Dobele, G., Bikovens, O., \& Telysheva, G. (2014). Characterization of Softwood and Hardwood Lignoboost Kraft Lignins with Emphasis on Their Antioxidant Activity. BioResources. 9(2), 2051-2068. DOI: 10.15376/biores.9.2.2051-2068.

Szczukowski, S., Tworkowski, J., Klasa, A., \& Stolarski, M. (2012). Productivity and Chemical Composition of Wood Tissues of Short Rotation Willow Coppice Cultivated on Arable Land. Rostl. Výroba. 48(9), 413-417. 
Technical Association of Pulp and Paper Industry. (2011). T222 Om-02 Lignin in Wood and Pulp. TAPPI test methods, 1-7.

Takkellapati, S., Li, T., \& Gonzalez, M.A. (2018). An Overview of Biorefinery-Derived Platform Chemicals from a Cellulose and Hemicellulose Biorefinery. Clean Technol. Environ. Policy. 20(7), 1615-1630. DOI: 10.1007/s10098-018-1568-5.

Vieito, C., Fernandes, É., Velho, M.V., \& Pires, P. (2018). The Effect of Different Solvents on Extraction Yield, Total Phenolic Content and Antioxidant Activity of Extracts from Pine Bark (Pinus Pinaster Subsp. Atlantica). Chem. Eng. Trans. 64, 127-132. DOI: 10.3303/CET1864022. 